\title{
Rákellenes tioszemikarbazonok és fémkomplexeik: a stabilitás és a biológiai aktivitás kapcsolata
}

\author{
ENYEDY Éva Anna ${ }^{a^{*}}$ \\ ${ }^{a}$ Szegedi Tudományegyetem, Szervetlen és Analitikai Kémiai Tanszék, Dóm tér 7., 6720, Szeged, Magyarország
}

\section{Bevezetés}

A tioszemikarbazonok (TSK-k, 1.a. ábra) és fémkomplexeik igen változatos szerkezetü és farmakológiai hatású vegyületek. ${ }^{1,2} \mathrm{Az}$ a-N-heterociklusos TSK-k rákellenes hatását már 1956-ban leírták; ${ }^{3}$ és a legismertebb képviselöjük a 3-amino-piridin-2-karbaldehid-TSK (Triapine, 1.b. ábra) klinikai fázis $\mathrm{I} / \mathrm{II}$ tesztelés alatt áll. ${ }^{4} \mathrm{~A}$ Triapine mono- és kombinált terápiákban bíztató eredményeket mutatott mieloid leukémia esetén, ${ }^{5}$ viszont rövid biológiai felezési ideje miatt szolid tumorokkal szemben jóval kevésbé hatékony és alkalmazását számos mellékhatás pl. hányás, methemoglobinémia kíséri. ${ }^{6}$ Mindezek a problémák további TSK-k fejlesztését ösztönözték, melyek között számos ígéretes $\alpha$-N-piridil TSK-t találunk (1.c. ábra), ${ }^{7-9}$ míg a 2015-ben humán klinikai kísérletekbe került COTI-2 (1.b. ábra) egy tetrahidrokinolin-származék. ${ }^{10}$

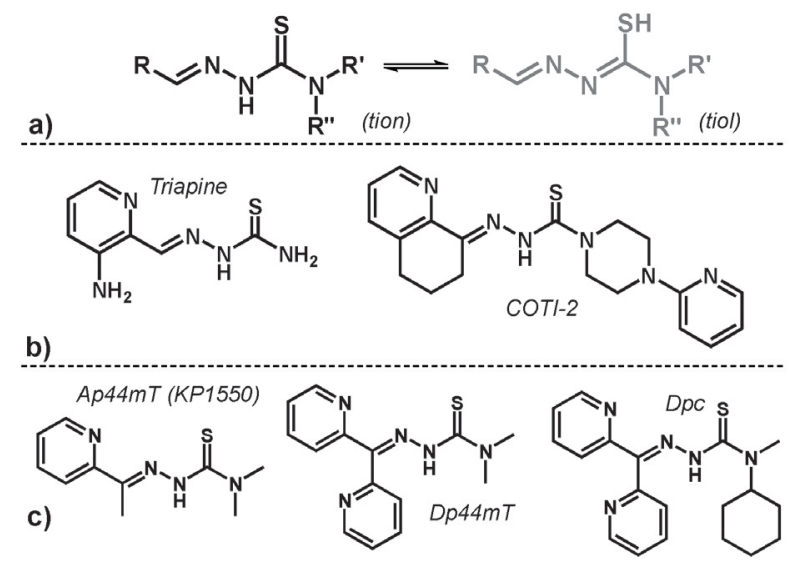

1. Ábra. Tioszemikarbazon (TSK) alapváz (a). Klinikai vizsgálatban lévő Triapine és COTI-2 (b). Néhány ígéretes TSK (c).

A Triapine és származékainak biológiai hatása elsősorban a DNS bioszintézisében kulcsszerepet játszó ribonukleotid reduktáz (RNR) enzim inhibícióján alapul. A RNR a dezoxiribonukleotidok képződését katalizálja, aktív centrumában két vasion és egy Tyr gyök található. A tumorsejtekben a fokozott osztódás miatt az RNR expresszió megnő, így ennek az enzim gátlása potenciális célpont a rákterápia során. Az általánosan elfogadott hatásmechanizmus alapján a Triapine az enzim R2 alegységével lép kölcsönhatásba. A képződő vas(II)-TSK komplex közvetlenül vagy még inkább az oxigénnel való reakciója során képződő reaktív oxigén származékok (ROS) által képes a katalitikus centrumban lévő Tyr gyököt kioltani, ami az enzim inaktiválásához vezet. ${ }^{11}$ Ennek következtében a TSK-k vas(II/III)ionokkal képzett komplexeinek oldatbeli stabilitása és redoxi tulajdonsága egyértelmüen befolyásol(hat)ja a TSK-k biológiai hatását.

A TSK-k alapvetően a kénen és az azometin-N-en keresztül koordinálódnak a vasionokhoz. A hidrazin-NH csoport deprotonálódhat és tiolátszerü kötési mód jöhet létre a tion-tiol tautomeriának (1.a. ábra) köszönhetően. Az $\alpha$-N-piridil TSK-k háromfogú, $\left(\mathrm{N}_{\text {piridil }}, \mathrm{N}, \mathrm{S}\right)$ donoratomokat tartalmazó ligandumok, semleges vagy anionos módon koordinálódnak. ${ }^{1,12}$ A koordinációs sajátságok tovább variálhatók a kén egyéb kalkogénatomra $(\mathrm{O}, \mathrm{Se})$, vagy pl. a piridil-N fenolos-OH csoportra való cseréjével. Mindez lehetővé teszi a stabilis komplexképzést számos egyéb fémionnal is a vasionokon kívül (pl. réz(II), platina(II), nikkel(II), cink(II), vanádium(IV/V)). ${ }^{12}$ Jól ismert az is, hogy nem csak a TSK-k, hanem fémkomplexeik is jelentős antitumor hatással bírnak. ${ }^{1,2}$ A komplexképzés megváltoztatja a lipofilitást, a töltést és a méretet, ezáltal a transzportfolyamatokat, de eltérö hatásmechanizmust is eredményezhet. Pl. a réz(II)-TSK komplexek antiproliferatív hatása ROS termelődéséhez köthető a fémkomplex fiziológiás redukálószerek általi redukcióját követően. ${ }^{13}$ Egyes réz(II)-TSK komplexek viszont a DNS topoizomeráz-IIa inhibícióján keresztül hatnak. ${ }^{14}$

A TSK-fémkomplexek fizikai-kémiai karakterizálása általában szilárd fázisban és szerves oldószerek oldatában történik a viszonylag rossz vízben való oldhatóságuk miatt. A farmakológiai hatás megértéséhez viszont alapvetően fontos, hogy ismerjük, milyen formában vannak jelen ezen fémkomplexek a vizes oldatokban, mert az eltérő lehet az eredeti szilárd formától. A különböző TSK-k RNR inhibíciójának megértéséhez pedig vas(II/III)ionokkal való kölcsönhatás teljesebb ismerete szükséges. Az irodalomban azonban meglehetősen hiányosak az ilyen jellegü oldategyensúlyi eredmények. Ez indokolta a 2009-töl elindított vizsgálatainkat, ${ }^{15}$ mely során számos különböző donorcsoportot és szubsztituenseket tartalmazó TSK (2. ábra) vas(II/III)-, réz(II)-, gallium(III)-, nikkel(II)-, cink(II)és vanádium(IV/V)ionokkal képzett komplexeinek oldatbeli viselkedését tanulmányoztuk. ${ }^{16-24} \mathrm{~A}$ képződő fémkomplexek összetételének, stabilitásának és redoxi tulajdonságainak összehasonlító jellemzése mellett az a célunk, hogy feltárjuk ezen paraméterek hogyan függnek össze a biológiai aktivitással. Jelen közleményben az eddig publikált legfontosabb eredményeinket foglaljuk össze. 


\section{A tioszemikarbazonok és fémkomplexeik oldat- egyensúlyi vizsgálata}

\subsection{A vizsgált tioszemikarbazonok proton disszociációs folyamatai és lipofilitásuk}

A TSK-k jellemzően vízben rosszul oldódó vegyületek, emiatt a legtöbb oldategyensúlyi mérést keverék-oldószerben $\quad(30 \% \quad(\mathrm{~m} / \mathrm{m}) \quad$ dimetil-szulfoxid $\left.\left(\mathrm{DMSO} / \mathrm{H}_{2} \mathrm{O}\right)\right)$ végeztük. A vizsgált TSK-k szerkezeti képletét a 2. ábra (és 1.b) mutatja.
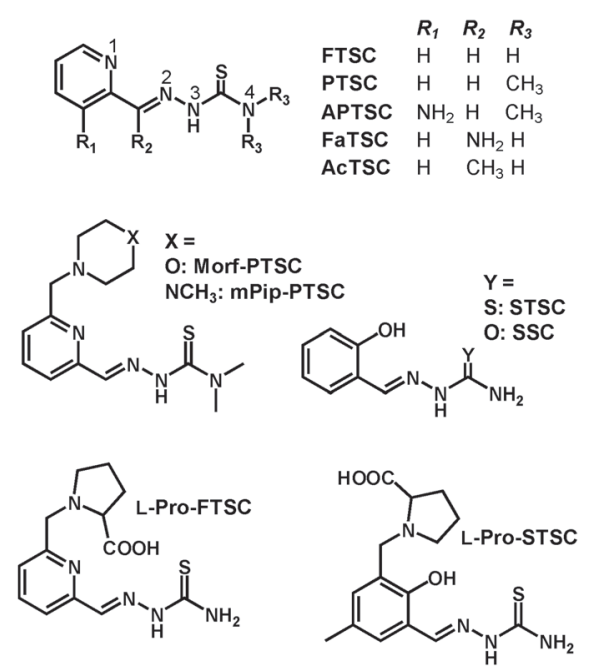

2. Ábra. A vizsgált tioszemikarbazonok szerkezeti képlete és rövidítésük. (SSC egy szemikarbazon)

Ha a ligandumok oldékonysága jobb volt ( $\mathrm{S} \geq 1 \mathrm{mM})$, ill. az alkalmazott mérési módszer nem igényelt magas koncentrációt (pl. spektrofotometria, fluorimetria) akkor tiszta vizes közegben is történtek mérések.

Néhány TSK pH-potenciometriás módszerrel meghatározott proton disszociációs állandójának negatív logaritmusát $\left(\mathrm{pK}_{\mathrm{a}}\right)$ mutatja az 1. táblázat. Az $\alpha-\mathrm{N}$-piridil TSK-knak két disszociábilis protonja van. ${ }^{15,16} \mathrm{Az}$ első deprotonálódási folyamat a piridinium nitrogénhez $\left(\mathrm{N}^{1} \mathrm{H}^{+}\right)$rendelhetö, míg a második a tioszemikarbazid-rész hidrazin nitrogénjéhez $\left(\mathrm{N}^{3} \mathrm{H}\right)$. Ebben a második lépcsőzetes folyamatban képződő $\mathrm{L}^{-}$formában a negatív töltés föképp a kénatomon lokalizálódik a tion-tiol tautomériának köszönhetően (1.a. ábra). A metil- és aminocsoportok jelenléte egyértelműen befolyásolja a ligandumok $\mathrm{pK}_{\mathrm{a}}$-it (1. táblázat); a hatás nagysága és iránya a szubsztituensek pozíciójától függ. Az N-terminális elektronküldő metilcsoportok $\left(\mathrm{R}_{3}\right)$ a $\mathrm{pK}_{1}-\mathrm{t}$ növelik, míg a $\mathrm{pK}_{2}-\mathrm{t} \sim$ fél nagyságrenddel csökkentik. Az $\mathrm{R}_{2}$ pozícióban lévő metilcsoport mindkét $\mathrm{pK}_{\mathrm{a}}$-t növeli. Viszont az aminocsoport ugyanezen pozícióban a $\mathrm{pK}_{1}$ - $\mathrm{t}$ gyakorlatilag nem befolyásolja, de megnöveli a $\mathrm{pK}_{2}$-t. A Triapinban lévő aminocsoport $\left(\mathrm{R}_{1}\right)$ jelentősen növeli a piridinium nitrogén bázicitását az FTSC alap ligandumhoz viszonyítva, de csökkenti a hidrazin nitrogén $\mathrm{pK}_{\mathrm{a}}$-ját. A piridin helyett fenol-gyürüt tartalmazó STSC-nek is két disszociábilis protonja van, de a teljesen protonált ligandum $\left(\mathrm{H}_{2} \mathrm{~L}\right)$ semleges. ${ }^{18} \mathrm{Az}$ első deprotonálódás itt a fenolos hidroxilcsoporton történik, míg a $\mathrm{pK}_{2}$ ugyanúgy a hidrazin nitrogénhez rendelhető. $\mathrm{A} \mathrm{HL}^{-}$forma negatív töltése felelős a $\mathrm{pK}_{2}$ több mint egy nagyságrenddel való növekedéséért az FTSC-hez hasonlítva. A kénatom oxigénre történő cseréje (STSC $\rightarrow$ SSC) a hidrazin nitrogén $\mathrm{pK}$-ját szintén megnöveli, értéke a mérhető $\mathrm{pH}$-tartományban már nem határozható meg. Így az SSC szemikarbazon esetében $\mathrm{pK}_{2}$ tartozik a fenolos hidroxilcsoport disszociációjához, míg $\mathrm{pK}_{1}$ a karbamoilcsoporthoz. ${ }^{22}$

Az 1. táblázatban szereplő ligandumok fiziológiás $\mathrm{pH}-\mathrm{n}$ a semleges HL formájukban vannak jelen, kivételt az STSC jelent. A semleges töltés segíti a vegyületek sejtes felvételét, viszont a rossz vízoldhatósághoz is hozzájárul. Az optimális hidro-lipofil sajátság megtalálása érdekében az FTSC, PTSC és STSC ligandumokra disszociábilis protonokat tartalmazó farmakofór szubsztituensek (Pro, morfolin, metil-piperazin) kerültek, és a kapott vegyületek már sokkal jobb vízoldékonyságúak voltak (2. ábra). ${ }^{19-21,23}$

\section{Táblázat}

Néhány kalkogénszemikarbazon proton disszociációs állandójának tízes alapú negatív logaritmusa $\left(\mathrm{p} K_{a}\right)^{\mathrm{a}}, n$-oktanol-víz megoszlási hányadosának logaritmusa $\left(\operatorname{lgD}_{7,4}\right)^{\mathrm{b}}$ és a ligandumok protonaltsági állapota $\mathrm{pH}=7,4-\mathrm{n}$. $\left\{\mathrm{t}=25,0^{\circ} \mathrm{C}, \mathrm{I}=0,1 \mathrm{M} \mathrm{KCl}\right\}$

\begin{tabular}{|c|c|c|c|c|}
\hline & $\mathrm{pK}_{1}$ & $\mathbf{p K}_{2}$ & $\lg \mathbf{D}_{7,4}$ & $\%(p H 7,4)$ \\
\hline Triapine & $3,92^{c}$ & $10,78^{\mathrm{c}}$ & $+0,85^{\mathrm{d}}$ & $100 \% \mathrm{HL}$ \\
\hline FTSC & $3,13^{\mathrm{e}}$ & $11,13^{\mathrm{e}}$ & $+0,73 \pm 0,01$ & $100 \% \mathrm{HL}$ \\
\hline PTSC & $3,38^{\mathrm{c}}$ & $10,54^{\mathrm{c}}$ & $+1,15^{\mathrm{f}}$ & $100 \% \mathrm{HL}$ \\
\hline APTSC & $4,31^{\mathrm{c}}$ & $10,29^{\mathrm{c}}$ & $+1,30^{\mathrm{f}}$ & $100 \% \mathrm{HL}$ \\
\hline FaTSC & $3,15^{\mathrm{e}}$ & $11,61^{\mathrm{e}}$ & - & $100 \% \mathrm{HL}$ \\
\hline AcTSC & $3,64^{\mathrm{e}}$ & $11,52^{\mathrm{e}}$ & - & $100 \% \mathrm{HL}$ \\
\hline STSC & $8,89^{d}$ & $12,59^{d}$ & $+1,74^{\mathrm{d}}$ & $96 \% \mathrm{H}_{2} \mathrm{~L}, 4 \% \mathrm{HL}$ \\
\hline SSC & $1,9^{\mathrm{g}}$ & $9,32^{\mathrm{g}}$ & $+1,04^{\mathrm{g}}$ & $100 \% \mathrm{HL}$ \\
\hline
\end{tabular}

a $30 \%(\mathrm{~m} / \mathrm{m}) \mathrm{DMSO} / \mathrm{H}_{2} \mathrm{O}$ oldószerelegyben meghatározva, L a ligandumok teljesen deprotonált formáját jelöli; ${ }^{b}$ További $\operatorname{lgD} D_{7,4}$ értékek: Morf-PTSC $=+0,61,{ }^{23} \mathrm{mPip}-\mathrm{PTSC}=-0,03,{ }^{23} \mathrm{~L}$-Pro-FTSC $=<-1,7,{ }^{20}$ L-Pro-STSC $=-0,60 ;{ }^{19 \mathrm{c}} 15$. hivatkozás; ${ }^{\mathrm{d}} 18$. hivatkozás; ${ }^{\mathrm{e}} 16$. hivatkozás; f 24 . hivatkozás; ${ }^{\mathrm{g}}$ 22. hivatkozás, SSC szemikarbazon.

A TSK-k $\mathrm{pK}_{\mathrm{a}}$-it UV-látható spektrofotometria segítségével is meg lehetett határozni, mert a proton disszociációs folyamatokat jól detektálható spektrális változások kísérik. Másrészt ezek a ligandumok a konjugált elektronrendszerüknek és merev szerkezetüknek köszönhetően fluoreszcensek, pH-függő emissziós spektrumaik felbontásával a savi disszociációs állandók szintén meghatározhatók. ${ }^{16,18,19}$ Emissziós maximumuk a látható hullámhossz-tartományba esik, ami lehetővé teszi a sejtbejutásuk és eloszlásuk monitorozását fluoreszcens mikroszkópiával. ${ }^{25}$

A ${ }^{1} \mathrm{H}$ NMR spektroszkópia segítségével nemcsak a TSK-k deprotonálódása követhető nyomon, hanem az izomerek jelenléte is. A $\mathrm{Z} / \mathrm{E}$ izoméria a $\mathrm{C}=\mathrm{N}^{2}$ kettős kötéshez kapcsolódóan jön létre, az izomerek aránya függ az oldószertől és a pH-tól is. Az $\alpha-\mathrm{N}$-piridil TSK-k poláris oldószerekben jellemzően az E-formában fordulnak elő. Az N-terminális dimetilezett származékok esetén a Z-izomer jelenléte is jelentős, pl. a PTSC-nél a Z izomer aránya eléri a $\sim 40 \%$-ot a $30 \%(\mathrm{~m} / \mathrm{m}) \quad \mathrm{DMSO} / \mathrm{H}_{2} \mathrm{O}$ elegyben semleges pH-n. ${ }^{16}$ 
A PTSC morfolin- és metil-piperazin-konjugátumai (2. ábra) extra deprotonálódó csoportokat tartalmaznak (Morf-PTSC: morfolinium- $\mathrm{NH}^{+}, \mathrm{mPip}-\mathrm{PTSC}$ : két piperazinium- $\mathrm{NH}^{+}$) a piridinium és hidrazin nitrogéneken kívül. Vizes oldatukban mért pH-függő ${ }^{1} \mathrm{H}$ NMR spektrumaik elemzésével nemcsak az E és $\mathrm{Z}$ izomerek arányát, hanem a deprotonálódásukhoz tartozó mikroállandókat is meghatároztuk, ahogyan a Morf-PTSC példája is mutatja a 3. ábrán. Az izomerek eltérö savi disszociációs állandói az egyes protonáltsági fokok esetén intramolekuláris hidrogénhidak jelentétével (3.b. ábra) jól értelmezhető voltak. ${ }^{23}$

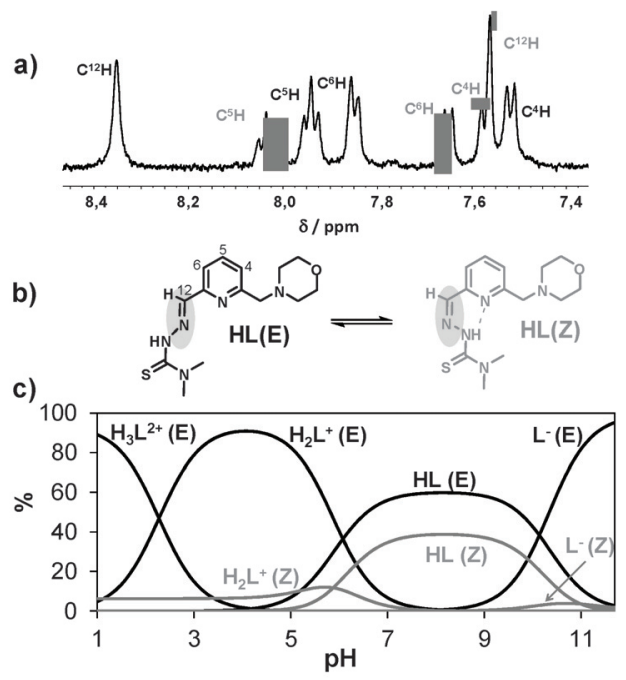

3. Ábra. A Morf-PTSC ligandum ${ }^{1} \mathrm{H}$ NMR spektruma az aromás régióban $\mathrm{pH}=7,58-\mathrm{n}\left(10 \% \mathrm{D}_{2} \mathrm{O}\right)$, szürke keretben a $\mathrm{Z}$ izomerhez tartozó csúcsok vannak jelölve (a). A HL forma E és Z izomerje (b) és

koncentrációeloszlási görbéi a ${ }^{1} \mathrm{H}$ NMR mérések alapján meghatározott mikroállandók ${ }^{23}$ segítségével számolva (c). $\left\{\mathrm{I}=0,1 \mathrm{M} \mathrm{KCl} ; \mathrm{t}=25^{\circ} \mathrm{C}\right\}$

A TSK-k fiziológiás $\mathrm{pH}-\mathrm{n}$ meghatározott megoszlási hányadosainak $\left(\lg \mathrm{D}_{7,4}, 1\right.$. táblázat) összehasonlításakor fontos figyelembe venni a vegyületek aktuális protonáltsági állapotát és így töltését, melyek a meghatározott $\mathrm{pK}_{\mathrm{a}}-\mathrm{k}$ segítségével könnyen megadhatók. A vizsgált TSK-k lipofilitása nagymértékben függ a szubsztituensektől. Az FTSC-hez hasonlítva megállapítható, hogy az $\mathrm{R}_{1}$ pozíciójú aminocsoport a lipofilitást csak kis mértékben, míg az N-terminális dimetilezés nagyobb mértékben növeli azt, a vártnak megfelelően. ${ }^{18,24}$ A piridin-nitrogén helyett fenolos $\mathrm{OH}$-csoport jelenléte a molekulában egy nagyságrenddel megnöveli a $\lg \mathrm{D}_{7,4}$ értéket (vö. FTSC és STSC), ${ }^{18}$ a kén oxigénre történő cseréje pedig csökkenti azt (vö. STSC és SSC). ${ }^{22}$ A farmakofór szubsztituensek (Pro, morfolin, metil-piperazin) bevezetése a hidrofilitás növelésével járt, de eltérő mértékben. A morfolincsoport $\mathrm{pH}=7,4-\mathrm{n}$ gyakorlatilag már deprotonált formában van a Morf-PTSC-ben, a molekula 97\%-ban semleges, ami miatt a $\operatorname{lgD}_{7,4}$ értéke a PTSC ligandumétól a várthoz képest csak kisebb mértékben alacsonyabb. ${ }^{23}$ Ezzel szemben a mPip-PTSC vegyületben a metil-piperidinium nitrogén 74\%-ban protonált, aminek köszönhetően a molekula hidrofilebb. ${ }^{23}$ A Pro-konjugátumok egyértelmúen hidrofilebb karakterüek a referenciavegyületükhöz képest: $\lg \mathrm{D}_{7,4}$ értékük több mint 2 nagyságrenddel kisebb, ami az aminosav-rész ikerionos szerkezetének $\left(\mathrm{N}_{\mathrm{Pro}} \mathrm{H}^{+}, \mathrm{COO}^{-}\right)$köszönhető. ${ }^{19,20}$

\subsection{Réz(II)komplexek}

A réz(II)-TSK komplexek rákellenes hatása már több mint negyven éve ismert, ${ }^{26}$ számos olyan komplexet állítottak elö, melyek a ligandumukhoz képest jóval nagyobb aktivitással bír. A komplexek nagy száma ellenére az irodalomban elvétve található termodinamikai adat a vizes oldatbeli viselkedésükre vonatkozóan. ${ }^{27} \mathrm{Az}$ általunk eddig vizsgált réz(II)-TSK komplexek ugyan változatos sztöchiometriát és koordinációs módot mutatnak, viszont közös jellemzőjük, hogy vizes közegben biológiailag releváns körülmények között $(\mathrm{pH}=7,4, \mu \mathrm{M}-\mathrm{os}$ koncentrációtartomány $)$ kiemelkedő stabilitásúak. ${ }^{15,18-20,22,23}$ A speciációt és a komplexek szerkezetét mindig pH-potenciometria, elektronspin rezonancia (ESR) spektroszkópia és UV-látható spektrofotometria kombinált használatával határoztuk meg, az egyes publikációkban megadott kísérleti körülménynek mellett.

Az $\alpha$-N-piridil és a szalicilaldehid TSK-k alapvetően háromfogú ligandumok, a réz(II)ionnal elsősorban mono-ligandumú komplexeket képeznek. Reprezentatív példaként az STSC komplexképzése látható a 4. ábrán. A savas pH-tartományban képződő protonált komplexben $\left([\mathrm{Cu}(\mathrm{LH})]^{+}\right)$a ligandum $\left(\mathrm{O}^{-}, \mathrm{N}, \mathrm{S}\right)$ donoratomokon keresztül koordinálódik, miközben a hidrazin-N még protonált formában van. Ennek deprotonálódásával jön létre a ligandum $\left(\mathrm{O}^{-}, \mathrm{N}, \mathrm{S}^{-}\right)$dianionos koordinációja a $[\mathrm{CuL}]$ komplexben, majd a pH-t tovább növelve képződik a vegyes hidroxido $[\mathrm{CuL}(\mathrm{OH})]^{-}$komplex. ${ }^{18}$

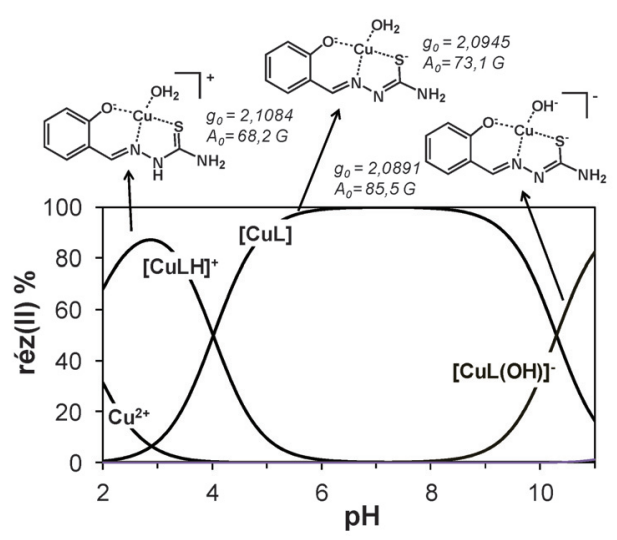

4. Ábra. A réz(II) - STSC (1:1) rendszer koncentrációeloszlási görbéi, a komplexek szerkezete és izotróp ESR paraméterei. ${ }^{18}$ $\left\{30 \%(\mathrm{~m} / \mathrm{m}) \mathrm{DMSO} / \mathrm{H}_{2} \mathrm{O} ; \mathrm{c}_{\mathrm{STSC}}=\mathrm{c}_{\mathrm{Cu}(\mathrm{II})}=1 \mathrm{mM} ; \mathrm{I}=0,1 \mathrm{M} \mathrm{KCl} ; \mathrm{t}=25^{\circ} \mathrm{C}\right\}$

Ugyanez a koordinációs séma figyelhető meg az L-Pro-STSC származéknál, ${ }^{19}$ és az $\alpha-\mathrm{N}$-piridil TSK-knál (pl. Triapine) is ${ }^{15}$ csak utóbbi esetben a fenoláto- $\mathrm{O}^{-}$helyett $\alpha$-piridin-N koordinálódik. Ugyanakkor az $\alpha$-N-piridil TSK-k ligandum feleslege esetén bisz-komplexek is képződnek, a TSK-k (N,N), (N,S-) koordinációjával különböző kötési izomerek jönnek létre. A Triapine, PTSC és APTS ligandumokkal ESR csendes $\left[\mathrm{Cu}_{2} \mathrm{~L}_{3}\right]^{+}$dimer részecske is megjelenik $\mathrm{pH}=5-9$ tartományban, melynek képződését elektrospray ionizációs tömegspektrometria (ESI-MS) módszerrel is sikerült igazolnunk. ${ }^{15} \mathrm{Az}$ L-Pro-FTSC esetén az aminosav-rész is részt vesz a 
koordinációban, a ligandum ötfogúként koordinálódik a $\left(\mathrm{COO}^{-}, \mathrm{N}_{\text {Pro }}, \mathrm{N}, \mathrm{N}, \mathrm{S}^{-}\right)$donoratomokon keresztül négyzetes piramisos geometriai elrendezésben, és kizárólag mono-ligandumú komplexek képződnek. ${ }^{20}$ A morfolin és a metil-piperazin-konjugátumok nitrogén donoratomja szintén részt vesz a fémion megkötésében, és az így létrejövő négyfogú koordináció jelentős stabilitásnövekedéssel jár az alap PTSC ligandumhoz viszonyítva. ${ }^{23}$

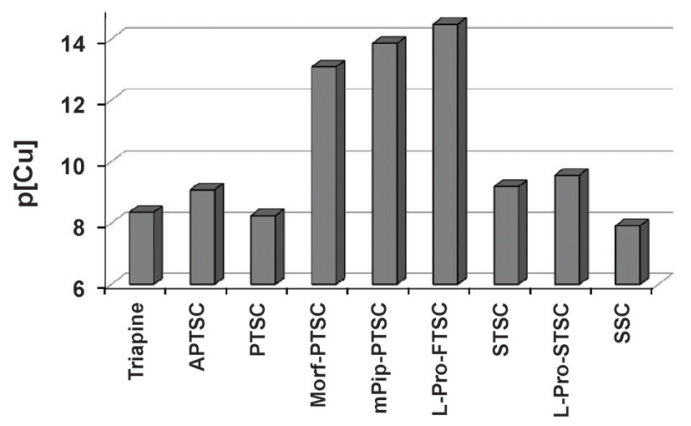

5. Ábra. A réz(II) ? TSK (1:1) rendszere a meghatározott stabilitási állandók $^{15,18-20,22,23}$ segítségével számolt $\mathrm{p}[\mathrm{Cu}]$ értékek $\mathrm{pH}=7,4-\mathrm{n}$. $\{30 \%$ $(\mathrm{m} / \mathrm{m}) \mathrm{DMSO} / \mathrm{H}_{2} \mathrm{O}$ vagy $\mathrm{H}_{2} \mathrm{O}$ : Morf-PTSC, mPip-PTSC, L-Pro-FTSC esetén; $\mathrm{c}_{\mathrm{L}}=\mathrm{c}_{\mathrm{Cu}(\mathrm{II})}=1 \mathrm{mM} ; \mathrm{I}=0,1 \mathrm{M} \mathrm{KCl} ; \mathrm{t}=25^{\circ} \mathrm{C}$ \} (SSC egy szemikarbazon)

A réz(II)-TSK komplexek stabilitása fiziológiás pH-n a ligandumok $\mathrm{pK}_{\mathrm{a}}-\mathrm{i}$ és a komplexekre meghatározott stabilitási szorzatok ${ }^{15,18-20,22,23}$ segítségével számolt pM (= $\mathrm{p}[\mathrm{Cu}]=-\lg [\mathrm{Cu}])$ értékek alapján jól összehasonlítható (5. ábra). Minél kisebb a ligandumhoz nem kötött fémion koncentrációja, azaz nagyobb a p $[\mathrm{Cu}]$ értéke annál nagyobb a ligandum fémkötő képessége az adott körülmények között. $\mathrm{Az}$ adatok alapján ezen rézkomplexek stabilitása kiemelkedő, mert $1 \mu \mathrm{M}-$ os oldatukban $\mathrm{pH}=7,4-\mathrm{n}$ a bomlásuk $\leq 1 \%$-os. $\mathrm{A} \mathrm{p}[\mathrm{Cu}]$ értékek összehasonlításával a következő hatások figyelhetők meg:

i) az N-terminális dimetilezés kis mértékben növeli a rézkomplexek stabilitását ( $v \ddot{0}$. Triapine és APTSC);

ii) a piridin- $\mathrm{N}$ fenolos- $\mathrm{OH}$ csoportra történő cseréje növeli a réz(II)-kötő képességet pH 7,4-n (vö. Triapine és STSC);

iii) a $\mathrm{S} / \mathrm{O}$ cserével jelentősen csökken a réz(II)komplexek stabilitása ( $v \ddot{o}$. STSC és SSC);

iv) a Pro jelenléte, ha donoratomjai nem vesznek részt a koordinációban, akkor alig növeli a réz(II)-kötés erősségét (vö. STSC és L-Pro-STSC);

v) a koordinációban résztvevő extra donoratomok jelentősen növelik a stabilitást (ld. Morf-PTSC, mPip-PTSC, L-Pro-FTSC).

Az 5. ábrán szereplö TSK-k közül a Triapine, APTSC, PTSC mutat kiemelkedő proliferációgátlást $\left(\mathrm{IC}_{50}<1 \mu \mathrm{M}, 41 \mathrm{M}\right.$ humán petefészek rákos sejtvonal), ${ }^{7}$ míg az L-Pro-STSC kicsi $\left(\mathrm{IC}_{50}=62\right.$ és $>100 \mathrm{mM}, \mathrm{CH} 1$ humán petefészek és SW480 vastagbélrák sejtvonalak), ${ }^{19}$ a többi ligandum elhanyagolható $\left(\mathrm{IC}_{50}>100 \mathrm{mM}\right.$ ) hatást gyakorol. ${ }^{18,20,22,23} \mathrm{~A}$ ligandumok antiproliferatív hatása nem korrelál a réz(II)komplexek stabilitásával. A Triapine és APTSC réz(II) komplexének aktivitása a ligandum saját hatásához hasonló, ${ }^{13}$ míg a TSK-konjugátumok (Morf-PTSC,
mPip-PTSC, L-Pro-FTSC, L-Pro-STSC) esetén a réz(II)komplexek antiproliferatív hatása egyértelmüen nagyobb. ${ }^{19,20,23}$ (A többi esetben még nem ismertek az $\mathrm{IC}_{50}$ értékek.) Ezek a citotoxikus réz(II)komplexek többnyire kiemelkedő stabilitásúak, de önmagában ez még nem magyarázhatja a nagyobb biológiai aktivitásukat, bizonyára szerepe van a redukálhatóságuknak is. Ennek össze-hasonlító vizsgálata jelenleg folyik laboratóriumainkban; elözetes méréseink jelentős különbségeket mutattak az egyes donorcsoportok esetén az aszkorbinsav és glutation általi redukciók mértékét és sebességét illetően.

\subsection{Vas(II)- és vas(III)komplexek}

A daganatos sejtek fokozott proliferációja miatt nagyobb a vasfelvételük, emiatt emelkedett a sejtfelszíni transzferrin receptor és a RNR enzim expressziója. Ez indokolta a vaskelátorok kemoterápiába történő potenciális bevezetését. Viszont a hematológiai betegségekben használt klasszikus vas(III)-kelátorok oxigén donoratomokat tartalmaznak (pl. deszferrioxamin, deferiprone) és meglehetősen hidrofilek, ami miatt antitumor hatásuk csekély. Az $\alpha-\mathrm{N}$-piridil TSK-k rákellenes hatása viszont nem csupán a vas(III)ionok megkötésén alapul, erős RNR inhibitorok, amihez szükséges, hogy fiziológiás körülmények között reverzibilis redoxi reakcióban vegyenek részt. Az $\alpha-\mathrm{N}$-piridil TSK-k hatásmechanizmusának jobb megértéséhez mindenképen szükséges a vas(II)- és vas(III)ionokkal képzett komplexek vizes oldatbeli stabilitásának az ismerete.

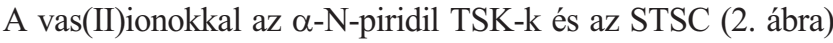
mono- ([FeLH], [FeL], [FeL(OH)]) és az oktaéderes geometriának köszönhetően biszkomplexeket $\left(\left[\mathrm{FeL}_{2} \mathrm{H}\right]\right.$ és $\left[\mathrm{FeL}_{2}\right]$ ) képeznek; a vas(III)ionokkal pedig döntően a deprotonált hidrazin-N-t tartalmazó [FeL] és $\left[\mathrm{FeL}_{2}\right]$ komplexek jönnek létre a vizsgált pH-tartományban. (A komplexek töltését az egyszerüség kedvéért nem adjuk meg.) A meghatározott stabilitási állandók ${ }^{15,16,18}$ birtokában elmondhatjuk, hogy $\mathrm{pH}=$ 7,4-n mindkét fémionnal az $\left[\mathrm{FeL}_{2}\right]$ összetételü komplex az uralkodó részecske. Ezekben a komplexekben a ligandumok háromfogúként, az $\left(\mathrm{N}, \mathrm{N}, \mathrm{S}^{-}\right)$vagy $\left(\mathrm{O}^{-}, \mathrm{N}, \mathrm{S}^{-}\right)$donoratomokon keresztül koordinálódnak (6.b. ábra).

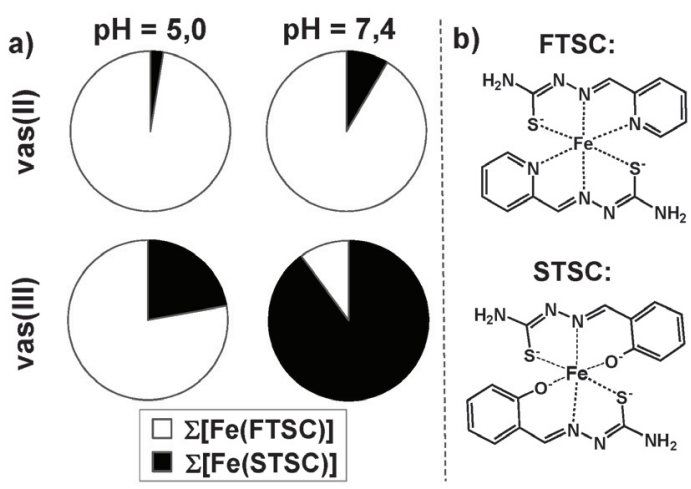

6. Ábra. A vas(II) (vagy vas(III)) ? STSC ? FTSC (1:2:2) hipotetikus rendszerben a fémionok megoszlása a két ligandum között $\mathrm{pH}=5,0$ és 7,4-n a vaskomplexek stabilitási szorzatai ${ }^{16,18}$ segítségével számolva (a). $\left\{30 \%(\mathrm{~m} / \mathrm{m}) \mathrm{DMSO} / \mathrm{H}_{2} \mathrm{O} ; \mathrm{c}_{\mathrm{Fe}}=1 \mathrm{mM} ; \mathrm{c}_{\mathrm{FTSC}}=\mathrm{c}_{\mathrm{STSC}}=2 \mathrm{mM} ; \mathrm{I}=0,1 \mathrm{M}\right.$ $\left.\mathrm{KCl} ; \mathrm{t}=25^{\circ} \mathrm{C}\right\}$ Az FTSC és STSC ligandumokkal képződő [ $\left.\mathrm{FeL}_{2}\right]$ biszkomplexek szerkezeti képlete (a töltés az egyszerüség kedvéért nincs feltüntetve) (b). 
A legegyszerübb $\alpha$-N-piridil TSK (FTSC) és az STSC esetén jól szemléltetető a +2 és +3 töltésü vasionok felé mutatott eltérő preferencia, melyet a 6.a. ábra mutat. A vas(II)ionok $\mathrm{pH}=7,4-n$ az FTSC-vel, míg a vas(III)ionok az STSC-vel képeznek stabilisabb komplexet a hard-szoft karakterüknek megfelelően.

A koordinálódó donorcsoport típusa mellett jelentősen kihatnak a vaskomplexek stabilitására az alap TSK vázhoz kapcsolódó szubsztituensek is, melyek befolyásolják az antiproliferatív hatást. Választott TSK-k (és az SSC szemikarbazon) sejtproliferációt gátló hatását jellemző $\mathrm{pIC}_{50}\left(=-\operatorname{lgIC} \mathrm{I}_{50}\right)$ értékeket mutat a 7.a. ábra.

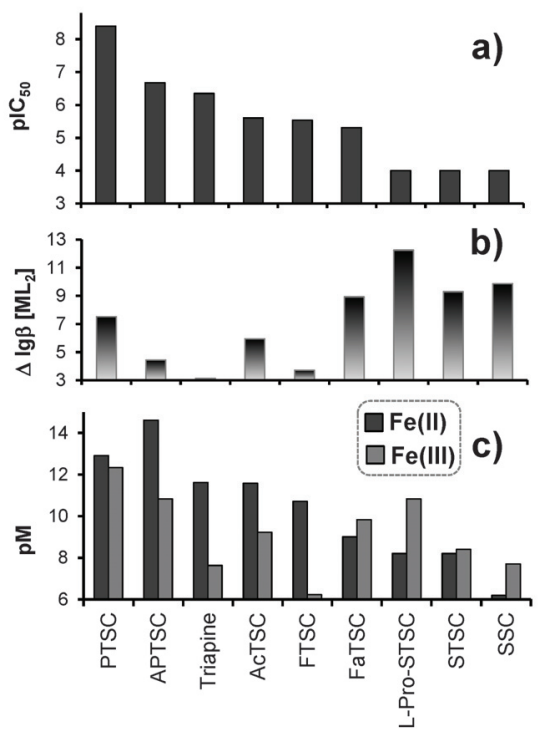

7. Ábra. Választott TSK ligandumok proliferációt gátló hatását jellemző $\mathrm{pIC}_{50}$ értékek $\left(\mathrm{IC}_{50}: \mathrm{mol} / \mathrm{dm}^{3}\right)$ humán petefészekrák sejtvonalakon $(\mathrm{CH} 1$, 41M) (a). ${ }^{18,19,22,28} \mathrm{~A}$ vas(III) és vas(II) biszkomplexek stabilitási szorzatainak különbsége: $\lg \beta\left[\mathrm{Fe}^{\mathrm{III}} \mathrm{L}_{2}\right]-\lg \beta\left[\mathrm{Fe}^{\mathrm{II}} \mathrm{L}_{2}\right]$ (b). A vas(II) - TSK és vas(III) - TSK rendszereke a meghatározott stabilitási állandók ${ }^{15,16,18,19,22}$ segítségével számolt pM értékek $\mathrm{pH}=7,4-\mathrm{n}$, ahol [M] a ligandumhoz nem kötött vasion egyensúlyi koncentrációja. $\left\{30 \%(\mathrm{~m} / \mathrm{m}) \mathrm{DMSO} / \mathrm{H}_{2} \mathrm{O} \mathrm{c}_{\mathrm{Fe}}=1\right.$ $\left.\mathrm{mM} ; \mathrm{c}_{\mathrm{L}}=10 \mathrm{mM} ; \mathrm{I}=0,1 \mathrm{M} \mathrm{KCl} ; \mathrm{t}=25^{\circ} \mathrm{C}\right\}$ (c).

Ezen TSK-k vas(II)- és vas(III)ionok felé mutatott affinitásbeli különbségét jellemzi az $\left[\mathrm{FeL}_{2}\right]$ biszkomplexek stabilitási szorzatainak különbsége (7.b. ábra). ${ }^{15,16,18,19,22} \mathrm{Ez}$ alapján elsősorban azok a ligandumok mutatnak csekély biológiai aktivitást (kis $\mathrm{pIC}_{50}$ értékek), melyek vas(III)komplexeinek nagyobb a lgb értéke a vas(II)komplexeihez hasonlítva (FaTSC, L-Pro-FTSC, STSC, SSC). A vas(II/III)komplexek stabilitási szorzatainak viszonyától függ a vas(III)/vas(II) rendszer redoxi potenciálja, ez viszont csak az $\alpha-\mathrm{N}$-piridil TSK-kra ismert a 7. ábrán lévő vegyületek közül. ${ }^{16} \mathrm{~A}$ meghatározott formálpotenciál értékek $+40-+160 \mathrm{mV}$ közé esnek az FaTSC kivételével; egyértelmü lineáris függést nem mutatnak az $\mathrm{IC}_{50}$ értékekkel. Viszont a kivételt jelentő FaTSC komplexeihez tartozó potenciál érték kisebb ( $E^{\prime}=$ $-170 \mathrm{mV}$ ), és ez a ligandum a sorozatban a legkevésbé aktív. Érdemes figyelembe venni a vasionokkal képződő komplexek stabilitásának megítélésekor a fémionok eltérő hidrolízisre való hajlamát is. Ennek megfelelően lettek pM értékek számolva $\mathrm{pH}=7,4-\mathrm{n}$, melyeket a 7 .c. ábra mutat.
Ezen értékek alapján elmondható, hogy összefüggést elsősorban a $\mathrm{pIC}_{50}$ és $\mathrm{p}[\mathrm{Fe}(\mathrm{II})]$ értékek között láthatunk: minél nagyobb p[Fe(II)], azaz a vas(II)-kötés erőssége, annál erősebb a ligandum sejtproliferációt gátló hatása. Ezen korreláció megerősítéséhez újabb ligandumok bevonásával további vizsgálatokat végzünk jelenleg.

\subsection{Gallium(III)komplexek}

A gallium(III)komplexek rákellenes hatása a fémion vas(III)ionokhoz hasonló koordinációs kémiai sajátságán és biokémiai anyagcsere útján alapul, viszont a gallium(III) nem redoxi aktív fiziológiás körülmények között és emiatt a $\mathrm{Fe} / \mathrm{Ga}$ csere után a vastartalmú biomolekula nem képes ellátni a funkcióját. Számos gallium(III)-TSK komplex jelentős citotoxicitást mutat, ${ }^{1,2,7}$ de oldatbeli stabilitásukról korábban nem volt információ.

A vizsgált gallium(III)-TSK komplexek a vártnak megfelelően hasonló szerkezetủek oldatban, mint a vas(III)komplexek. ${ }^{16,18,22}$ A meghatározott stabilitási szorzatok egyértelmű lineáris korrelációt mutatnak a vas(III)komplexek megfelelő állandóival. Azaz a gallium(III) is egyértelmüen stabilisabb komplexet képez az $\left(\mathrm{O}^{-}, \mathrm{N}, \mathrm{S}^{-}\right),\left(\mathrm{O}^{-}, \mathrm{N}, \mathrm{O}^{-}\right)$donoratomokat tartalmazó STSC, SSC ligandumokkal az $\left(\mathrm{N}, \mathrm{N}, \mathrm{S}^{-}\right)$donor $\alpha-\mathrm{N}$-piridil TSK-okhoz viszonyítva. Ugyanakkor a stabilitásuk jóval kisebb a vas(III)komplexekéhez képest, olyannyira hogy pl. az FTSC esetén a $\left[\mathrm{GaL}_{2}\right]^{+}$komplex $0,5 \mathrm{mM}$-os oldatában $\mathrm{pH}=7,4-\mathrm{n}$ a bomlás $100 \%$-osnak tekinthetö, de az STSC esetén is ez $52 \%$. Biológiai hatásuk így nem köthető a komplex eredeti formájához, valószínű a ligandum-, fémioncsere.

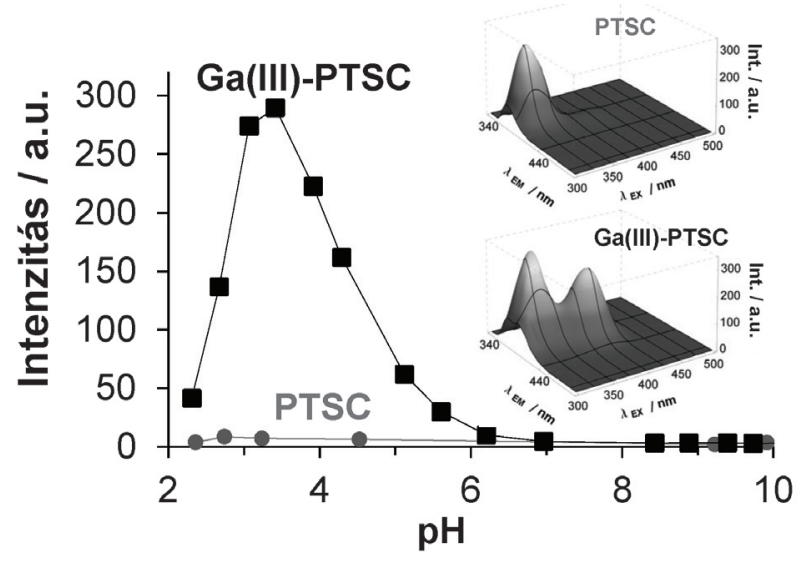

8. Ábra. A PTSC és a gallium(III) - PTSC (1:2) rendszer fluoreszcens emissziós intenzitása $470 \mathrm{~nm}$-en a pH függvényében vízben. ${ }^{16}\left\{1_{\mathrm{EX}}=\right.$ $\left.395 \mathrm{~nm} ; \mathrm{c}_{\mathrm{Ga}(\mathrm{III})}=5 \mathrm{mM} ; \mathrm{c}_{\mathrm{L}}=10 \mathrm{mM} ; \mathrm{I}=0,1 \mathrm{M} \mathrm{KCl} ; \mathrm{t}=25^{\circ} \mathrm{C}\right\}$ Beszúrt ábrák: a PTSC ligandum és a gallium(III) ? PTSC (1:1) rendszer 3D fluoreszcens spektrumai $\mathrm{pH}=4,2-\mathrm{n}$.

Fontos megemlíteni, hogy a gallium(III)-TSK komplexek fluoreszcensek, gerjesztési és emissziós spektrumuk eltér a szabad ligandumétól, ahogy a 8 . ábra 3D spektrumai is mutatják. Ez lehetőséget ad a komplexképződés monitorozására tiszta vizes közegben a módszer alacsony koncentráció igénye miatt. A 8. ábra a PTSC és a komplex emissziós intenzitásának pH-függését mutatja. A két görbe lefutásának különbsége egyértelmüen rámutat arra, hogy a fémkomplex csak pH $=2-6$ között van jelen az oldatban, nagyobb pH-kon disszociál. 


\subsection{Vanádium(IV/V)komplexek}

Az irodalomban számos citotoxikus vanádium(IV/V)-TSK komplexet is leírtak, ${ }^{2}$ de vizes oldatbeli stabilitásukról nem volt adat. A pH-potenciometriás, ESR spektroszkópiás és UV-látható spektrofotometriás vizsgálataink azt mutatták, ${ }^{22,24}$ hogy kizárólag monokomplexek képződnek ([MLH], [ML], [ML(OH)]), és pH = 7,4-n a [V $\left.\mathrm{V}^{\mathrm{IV}} \mathrm{OL}(\mathrm{OH})\right]$ ill. $\left[\mathrm{V}^{\mathrm{V}} \mathrm{O}_{2} \mathrm{~L}\right]$ részecskék a dominánsak. Stabilitásuk nagymértékben függ a fémion oxidációs állapotától: a $\mathrm{V}^{\mathrm{V}} \mathrm{O}_{2}{ }^{+}$komplexek a nagyobb stabilitásúak; másrészt függ a koordinálódó donoratomokról. A stabilitási trend mindkét oxidációs állapotú fémionnal: STSC $>$ SSC $>$ PTSC > APTSC $>$ Triapine. A vanádium(IV) Triapine-nal képzett komplexe olyan kis stabilitású, hogy fiziológiás $\mathrm{pH}-\mathrm{n}$ disszociációja teljesnek mondható már az 1 mM-os koncentrációjú oldatában is. ${ }^{24}$ Így nem meglepő, hogy ezen ligandumok körében csak a vanádium(V)-STSC komplex proliferáció gátlása haladta meg a ligandum önálló hatását. ${ }^{24}$

\section{3. Összefoglalás}

Rákellenes vegyületek fejlesztésekor alapvetően fontos a szerkezet-aktivitás összefüggések vizsgálata. A TSK-k antitumor hatása elsősorban a vastartalmú RNR enzim inhibícióján alapul és így összefüggésbe hozható a vegyületek vasionok felé mutatott affinitásával. Másrészt a TSK-k egyes fémkomplexei is jelentős antiproliferatív hatással bírnak rákos sejteken, hatásmechanizmusuk megértéséhez szükséges a komplexek fiziológiás körülmények közötti formáinak és azok stabilitásának ismerete. Mindezek miatt végeztünk összehasonlító oldategyensúlyi vizsgálatokat változatos szerkezetű és koordinációs tulajdonságú TSK-kkal. A legfontosabb eredményeket foglaltuk össze jelen közleményben a ligandumok lipofilitása, protonálódási és réz(II)-, vas(II)-, vas(III)-, gallium(III)-, vanádium(IV)- és vanádium(V)-ionokkal való komplexképzési folyamataikkal kapcsolat-ban, összefüggést keresve a rákellenes hatással.

Megállapítottuk, hogy a vizsgált TSK-knak a metil-piperazin-konjugátum kivételével fiziológiás $\mathrm{pH}-\mathrm{n}$ a semleges töltésü formájuk az uralkodó. Lipofilitásuk függ az alapváztól: a szalicilaldehid származékok lipofilebbek, mint az $\alpha$-N-piridil típusúak; és függ a szubsztituensektől is: az N-terminálisan metilezett vegyületek lipofilebbek, míg a TSK-konjugátumok (Pro, morfolin, metil-piperazin) hidrofilebbek.

A vizsgált fémionok körében a réz(II)komplexek adódtak a legstabilisabbnak, különösen kiemelkedő a stabilitás a négy- ill. ötfogú ligandumként koordinálódó Morf-PTSC, mPip-PTSC és L-Pro-FTSC esetében. Ezen utóbbi vegyületek réz(II)komplexeinek proliferáció gátló hatása egyértelmüen meghaladja a ligandumok saját hatását. A vas(II/III)ionokkal semleges pH-n biszkomplexek képződnek; és a TSK-k affinitása a vas kétféle oxidációs állapotú ionjához nagymértékben függ a koordinálódó donoratomok típusától. Az $\left(\mathrm{N}, \mathrm{N}, \mathrm{S}^{-}\right)$kötésmód a vas(II), míg az $\left(\mathrm{O}^{-}, \mathrm{N}, \mathrm{S}^{-}\right)$koordináció a vas(III)ionokkal való komplexképzésnek kedvez. A komplexek stabilitását a szubsztituensek is befolyásolják. Azt találtuk, hogy a TSK-k antiproliferatív hatása erősen korrelál a
vas(II)komplexek stabilitásával. A TSK-k gallium(III)ionokkal képzett komplexeinek összetétele és geometriája igen hasonló a vas(III)ionokkal képződőkkel, viszont alapvető különbség a gallium(III)komplexek kisebb stabilitása. Ennek megfelelően biológiai hatásuk a legtöbb esetben nem köthető a komplex eredeti, $\left[\mathrm{GaL}_{2}\right]$ formájához. A vanádium(IV/V) ionokkal mono-ligandumú komplexek képződnek, melyek stabilitása az $\alpha-\mathrm{N}$-piridil TSK-k esetén jóval kisebb az $\left(\mathrm{O}^{-}, \mathrm{N}, \mathrm{S}^{-}\right)$donoratomokat tartalmazó STSC ligandummal képzett komplexekhez képest. A ligandum önálló antiproliferatív hatását csak a vanádium(V) STSC ligandummal képzett komplexe haladta meg.

A meghatározott oldategyensúlyi adatok segítségével megadható a TSK-k és fémkomplexeik megjelenési formája fiziológiás pH-n, vizes oldatban, mely gyakran különbözik az eredetileg szilárd formában előállítottól, viszont nagyobb valószínüséggel lehet felelős a biológiai hatásért. Ezen aktív formák ismerete mindenképpen hozzájárul a hatásmechanizmus értelmezéséhez.

\section{Köszönetnyilvánítás}

A közlemény az OTKA PD103905 pályázat és a Bolyai János Kutatási Ösztöndíj támogatásával készült. A szerző köszönetet mond az idézett cikkekben szereplő társszerzők, elsősorban Bernhard K. Keppler, Christian R. Kowol, Vladimir B. Arion (University of Vienna) és Nagy Nóra Veronika (MTA, TTK) közremüködésért.

\section{Hivatkozások}

1. Dilworth, J.R.; Hueting, R. Inorg. Chim. Acta. 2012, 389, 3-15. https://doi.org/10.1016/j.ica.2012.02.019

2. Beraldo, H.; Gambino, D. Mini-Rev. Med. Chem. 2004, 4, 31-39.

3. Brockman, R.W.; Thomson, J.R.; Bell, M.J.; Skipper, H.E. Cancer Res. 1956, 16, 167-170.

4. Merlot, A. M.; Kalinowski, D. S.; Richardson, D. R. Antioxid. Redox Signal. 2013, 18, 973-1006. https://doi.org/10.1089/ars.2012.4540

5. Zeidner, J.F.; Karp, J.E.; Blackford, A.L.; Smith, B.D.; Gojo, I.; Gore, S.D.; Levis, M.J.; Carraway, H.E.; Greer, J.M.; Ivy, S.P.; Pratz, K.W.; McDevitt, M.A. Haematologica 2014, 99, 672-678.

https://doi.org/10.3324/haematol.2013.097246

6. Kolesar, J.; Brundage, R. C.; Pomplun, M.; Alberti, D.; Holen, K.; Traynor, A.; Ivy, P.; Wilding, G. Cancer Chemother. Pharmacol. 2011, 67, 393-400.

7. Kowol, C.R; Berger, R.; Eichinger,R.; Roller, A.; Jakupec, M.A.; Schmidt, P.P.; Arion, V.B.; Keppler, B.K. J. Med. Chem. 2007, 50, 1254-1265. https://doi.org/10.1021/jm0612618

8. Richardson, D.R.; Ka linowski, D.S.; Richardson, V.; Sharpe, P.C.; Lovejoy, D.B.; Islam, M.; Bernhardt P.V. J. Med. Chem. 2009, 52, 1459-1470. https://doi.org/10.1021/jm801585u

9. Jansson, P.J.; Kalinowski, D.S.; Lane, D.J.R.; Kovacevic, Z.; Seebacher, N.A.; Fouani, L.; Sahni, S.; Merlot, A.M. ; Richardson D.R. Pharmacol. Res. 2015, 100, 255-260. https://doi.org/10.1016/j.phrs.2015.08.013

10. https://clinicaltrials.gov/ct2/show/NCT02433626 (Letöltés időpontja: 2016.04.20.) 
11. Shao, J.; Zhou, B.; Di Bilio, A.J.; Zhu, L.; Wang, T.; Shih, C.Q.J.; Yen, Y. Mol. Cancer Ther. 2006, 5, 586-592. https://doi.org/10.1158/1535-7163.MCT-05-0384

12. Lobana, T.S.; Sharma, R.; Bawa, G.; Khanna, S. Coord. Chem. Rev. 2009, 253, 977-1055. https://doi.org/10.1016/j.ccr.2008.07.004

13. Kowol, C.R; Heffeter, P.; Miklos, W.; Gille, L.; Trondl, R.; Cappellacci, L.; Berger, W.; Keppler, B.K. J. Biol. Inorg. Chem. 2012, 17, 409-423. https://doi.org/10.1007/s00775-011-0864-X

14. Zeglis, B.M.; Divilov, V.; Lewis, J.S. J. Med. Chem. 2011, 54, 2391-2398. https://doi.org/10.1021/jm101532u

15. Enyedy, E.A.; Nagy, N.V.; Zsigoě, Eě.; Kowol, C.R.; Arion, V.B.; Roller, A.; Keppler, B.K.; Kiss, T. Eur. J. Inorg. Chem. 2010, 1717-1728.

16. Enyedy, E.A.; Primik, M.F.; Kowol, C.R.; Arion, V.B.; Kiss, T.; Keppler, B.K. Dalton Trans. 2011, 40, 5895-5905. https://doi.org/10.1039/c0dt01835j

17. Popovic-Bijelic, A.; Kowol, C.R.; Lind, M.E.S.; Luo, J.; Himo, F.; Enyedy, E.A.; Arion, V.B.; Gräslund, A. J. Inorg. Biochem. 2011, 105, 1422-1431.

18. Enyedy, E.A.; Zsigoě, E.; Nagy, N.V.; Kowol, C.R.; Roller, A.; Keppler, B.K.; Kiss, T. Eur. J. Inorg. Chem. 2012, 4036-4047.

19. Milunovic, M.N.M.; Enyedy, E.A.; Nagy, N.V.; Kiss, T.; Trondl, R.; Jakupec, M.A.; Keppler, B.K.; Krachler, R.; Novitchi, G. ; Arion, V.B. Inorg. Chem. 2012, 51, 9309-9321.

20. Bacher, F.; Enyedy, E.A.; Nagy, N.V.; Rockenbauer, A.; Bognar, G.M.; Trondl, R.; Novak, M.S.; Klapproth, E.; Kiss, T.; Arion, V.B. Inorg. Chem. 2013, 52, 8895-8908.
21. Bacher, F.; Dömötör, O.; Kaltenbrunner, M.; Mojovic, M.; Popovic-Bijelic, A.; Gräslund, A.; Ozarowski, A.; Filipović, L.; Radulović, S.; Enyedy, E.A.; Arion, V.B. Inorg. Chem. 2014, 53, 12595-12609.

22. Enyedy, E.A.; Bognár, G.M.; Nagy, N.V.; Jakusch, T.; Kiss, T.; Gambino, D. Polyhedron 2014, 67, 242-252. https://doi.org/10.1016/j.poly.2013.08.053

23. Bacher, F.; Dömötör, O.; Chugunova, A.; Nagy, N.V.; Filipović, L.; Radulović, S.; Enyedy, E.A.; Arion, V.B. Dalton Trans. 2015, 44, 9071-9090. https://doi.org/10.1039/C5DT01076D

24. Kowol, C.R.; Nagy, N.V.; Jakusch, T.; Roller, A.; Heffeter, P.; Keppler, B.K.; Enyedy, E.A. J. Inorg. Biochem. 2015, 152, 62-73. https://doi.org/10.1016/j.jinorgbio.2015.08.023

25. Kowol, C.R.; Trondl, R.; Arion, V.B.; Jakupec, M.A.; Lichtscheidl, I.; Keppler, B.K. Dalton Trans. 2010, 39, 704-706. https://doi.org/10.1039/B919119B

26. Santini, C.; Pellei, M.; Gandin, V.; Porchia, M.; Tisato, F.; Marzano. C. Chem. Rev. 2014, 114, 815-862.

27. Gaál, A.; Orgován, G.; Polgári, Z.; Réti, A.; Mihucz, V.G.; Bősze, S.; Szoboszlai, N.; Streli, C. J. Inorg. Biochem. 2014, 130, 52-58. https://doi.org/10.1016/j.jinorgbio.2013.09.016

28. Kowol, C.R; Trondl, R.; Heffeter, P.; Arion, V.B.; Jakupec, M.A.; Roller, A.;Galanski, M.; Berger, W.; Keppler, B.K. J. Med. Chem. 2009, 52, 5032-5043. https://doi.org/10.1021/jm900528d

\section{Anticancer thiosemicarbazones and their metal complexes: relationship between stability and bioactivity}

Thiosemicarbazones (TSCs) are versatile compounds regarding their structures, metal binding abilities and pharmacological properties including anticancer activity. Among the TSCs the most studied representative is Triapine (3-aminopyridine-2carboxaldehyde thiosemicarbazone) which has already been evaluated in several clinical phase I and II trials showing encouraging results in the treatment of hematological malignancies such as myeloid leukemia, although was found to be inactive against solid tumors. A novel promising TSC, COTI-2 has recently entered into human clinical trials. Due to the success of these compounds TSCs and their metal complexes have gained improving focus and attention. The iron-requiring enzyme ribonucleotide reductase is most probably the main target for Triapine and related TSCs. This enzyme is responsible for the production of deoxyribonucleotides required for the DNA synthesis, thus for the cell proliferation. Triapine acts as an efficient inhibitor of this enzyme via destruction of the iron-dependent tyrosyl radical. Consequently, the iron binding ability of the TSCs and the redox properties of their iron complexes are assumed to affect the biological activity. Copper(II) complexes of TSCs show remarkable antitumor effect as well, although their efficacy is mostly connected to their cellular redox cycling. Some copper(II) complexes are reported to inhibit efficiently topoisomerase-IIa. Despite the large number of TSC compounds studies on their solution behavior are fairly rare in the literature. However, the knowledge of the speciation and the most plausible chemical forms of these compounds in aqueous solution under physiological conditions is a mandatory prerequisite. Characterizations of these TSC complexes are generally performed in solid phase or in the solutions of organic solvents in most of the studies in the literature. Our aim is to understand how the structural changes on the TSC scaffold affect the protonation processes, lipophilicity, the metal binding abilities and the redox properties revealing correlation between these parameters and their antiproliferative activity. In the present work the most important results obtained on the copper(II), iron(II/III), gallium(III) and vanadium(IV/V) complexes of various TSCs are summarized.

Triapine belongs to the family of $\alpha-\mathrm{N}$-pyridyl TSCs and possesses two dissociable protons. Its first deprotonation process can be attributed to the pyridinium unit, while the second one to the hydrazinic $\mathrm{N}^{2}-\mathrm{H}$ group of the thiosemicarbazide moiety. In the latter the resulting negative charge is mainly localized on the $\mathrm{S}$ atom via the thione-thiol tautomeric equilibrium. The presence of the various substituents such as methyl and amino groups on the $\alpha$-pyridyl TSC backbone undoubtedly affects these deprotonation processes. Based on the proton dissociation constants determined it was pointed out that the studied TSCs are neutral at physiological $\mathrm{pH}$ except a methylpiperazine conjugate. Their hydro-lipophilic character also strongly depends on the TSC scaffold itself and the type of the substituents. Namely, the salicylaldehyde TSC is more lipophilic than the corresponding $\alpha-\mathrm{N}$-pyridyl TSC, the $\mathrm{N}$-terminally dimethylated compounds are more lipophilic, while the pharmacophoric group containing TSC-conjugates (Pro, morpholine, methylpiperazine) display higher hydrophilicity, thus higher water solubility. The TSCs usually have limited water solubility, thus most of the solution 
equilibrium studies were performed in solvent mixtures $(30 \%$ dmso/water). Notably the studied TSCs are fluorescent compounds due to their rigid structure and the conjugated electron system. Therefore the $\mathrm{pK}_{\mathrm{a}}$ values of these ligands could be determined via the deconvolution of the $\mathrm{pH}$-dependent emission fluorescence spectra even in pure water at the applied low concentrations. ${ }^{1} \mathrm{H}$ NMR spectroscopy was found to be advantageous for the detection of the presence of $\mathrm{Z} / \mathrm{E}$ isomers with respect to the $\mathrm{C}=\mathrm{N}^{2}$ azomethine double bond and for the determination of the microscopic proton dissociation constants of these isomers as well.

The $\alpha$-N-pyridyl and salicylaldehyde TSCs are basically tridentate ligands coordinating via $\left(\mathrm{N}_{\text {pyr }}, \mathrm{N}, \mathrm{S}\right)$ or $\left(\mathrm{O}^{-}, \mathrm{N}, \mathrm{S}\right)$ donor set, respectively. The speciation and the solution structures of the complexes were determined by the combined use of pH-potentiometry, UV-visible spectrophotometry, fluorometry, ${ }^{1} \mathrm{H},{ }^{51} \mathrm{~V}$ NMR and EPR spectroscopy depending on the type of the studied metal ions. However, the studied copper(II) complexes display the formation of species with diversified stoichiometry in solution (e.g. $[\mathrm{CuLH}],[\mathrm{CuL}],[\mathrm{CuL}(\mathrm{OH})]$, $\left.\left[\mathrm{CuL}_{2} \mathrm{H}\right],\left[\mathrm{CuL}_{2}\right],\left[\mathrm{Cu}_{2} \mathrm{~L}_{3}\right]\right)$, a common feature was observed, namely their significantly high stability under biologically relevant conditions such as $\mathrm{pH} 7.4$ and $\mathrm{mM}$ concentration range. Among the studied metal complexes copper(II) compounds were found to be the most stable in solution, especially in the case of the Morf-PTSC, mPip-PTSC and L-Pro-FTSC ligands (Fig. 2.) which are able to coordinate to the metal center via four or five donor atoms due to the presence of additional functional groups. It was also observed that the $\mathrm{N}$-terminally dimethylation can slightly increase the stability of the copper(II) complexes. The antiproliferative activity of these latter copper(II) complexes exceeds that of the metal-free ligand precursors. Based on the stability data it could be concluded that the exchange of the pyridine nitrogen to the phenolic hydroxyl group increases the copper(II) binding ability of TSCs at pH 7.4, while the sulfur/oxygen exchange in the thiosemicarbazide moiety leads to significant decrease in the complex stabilities. The tridentate TSCs form bis-ligand complexes with iron(II) and iron(III) ions at neutral $\mathrm{pH}$, and the affinity towards the iron ions in the two kinds of oxidation states is strongly affected by the type of the coordinating donor atom sets. The $\left(\mathrm{N}, \mathrm{N}, \mathrm{S}^{-}\right)$ binding mode is favored by the iron(II) ions, while iron(III) ions form higher stability complexes with ligands with $\left(\mathrm{O}^{-}, \mathrm{N}, \mathrm{S}^{-}\right)$ donor set at neutral $\mathrm{pH}$. The stability of the complexes is modified by the various substituents. It was found that the antiproliferative activity of the TSCs shows correlation with the stability of the iron(II) complexes. The stoichiometry and structure of the gallium(III) TSC complexes are rather similar to those of the iron(III) species, although their solution stability is much lower. The stability constants of the $\left[\mathrm{Ga}(\mathrm{III}) \mathrm{L}_{2}\right]$ complexes are lower by 2-3 orders of magnitude showing an unambiguous linear correlation with those of the $\left[\mathrm{Fe}(\mathrm{III}) \mathrm{L}_{2}\right]$ complexes. Thus gallium(III) ions exhibit higher affinity towards ligands possessing $\left(\mathrm{O}^{-}, \mathrm{N}, \mathrm{S}^{-}\right)$and $\left(\mathrm{O}^{-}, \mathrm{N}, \mathrm{O}^{-}\right)$donor sets. E.g. in the case of the simplest $\alpha-\mathrm{N}$-pyridyl TSC (FTSC) the $\left[\mathrm{Ga}(\mathrm{III}) \mathrm{L}_{2}\right]$ complex suffers a complete decomposition at $\mathrm{pH} 7.4$ already in the $\mathrm{mM}$ concentration range. Therefore the biological effect of the gallium(III) complexes of TSCs in many cases cannot be connected to the original chemical form, $\left[\mathrm{Ga}(\mathrm{III}) \mathrm{L}_{2}\right]$, obtained in solid phase. It should be noted that the gallium(III) complexes of TSCs are fluorescent, which allows the monitoring the complexation processes in pure aqueous solution in fairly low concentrations. The tridentate TSCs form mono-ligand complexes with vanadium(IV/V) ions exclusively such as $[\mathrm{MLH}],[\mathrm{ML}],[\mathrm{ML}(\mathrm{OH})]$. The predominating species are $[\mathrm{V}(\mathrm{IV}) \mathrm{OL}(\mathrm{OH})]$ and $\left[\mathrm{V}(\mathrm{V}) \mathrm{O}_{2} \mathrm{~L}\right]$ at physiological $\mathrm{pH}$. The stability of the complexes depends on the oxidation state of the vanadium ion and the type of the coordinating donor atoms. Namely, vanadium(V) forms the higher stability complexes and the stability of the $\alpha$-N-pyridyl TSC complexes is much lower compared to that of the salicylaldehyde TSC.

On the basis of the determined stability constants the actual chemical forms of the TSCs and their metal complexes in solution can be predicted, which may differ from the original composition and can be responsible for the biological effect. The deeper knowledge of these active forms and their solution stability contributes to understanding of the alterations in the efficacy of these compounds, the mechanism of action and may help in the development of more effective chemotherapeutics. 